\section{FIRST RECORD OF A NEMOPTERID (NEUROPTERA: NEMOPTERIDAE) FROM MAHARASHTRA}

\author{
R.M. Sharma, S.S. Talmale and P.P. Kulkarni \\ Zoological Survey of India, Western Regional Station, Vidyanagar, \\ Sector 29, PCNT Post office, Rawet Road, Pune, Maharashtra \\ 411044, India.
}

During the course of faunistic survey of Tadoba-Andhari Tiger Reserve, Chandrapur District, Maharashtra in April 2000, we encountered altogether five specimens of Croce filipennis Westwood, a member of family Nemopteridae of order Neuroptera. Again one of us (SST) could collect a single specimen of the same species from Lakhani Village, Bhandara District, Maharashtra (approximately $150 \mathrm{~km}$. away from Tadoba) on 27 April 2000. Earlier, in 1998 we had collected a single mutilated specimen of the same species from Pune. Though seldom seen, all these collections reveal the probability of wide distribution of this species in Maharashtra State.

The family Nemopteridae includes very unusual and highly specialised insects. They are commonly known as Threadwinged or Spoon-winged Lacewings. Adults look like large mosquitoes; with normal front wings and typical neuropteran structure; hindwings very narrow, thread-like and longer than body. The head is prolonged into a rostrum. Antennae are moderately long, not clubbed or thickened at the end.

Neuroptera is an important order of predaceous insects, which includes many structurally and biologically heterogenous and remarkable members. The neuropterans are rarely abundant in numbers and most are weak in flight. They feed on soft-bodied insects including pests in their larval and adult stages.

Croce filipennis is a striking and graceful insect. It flies with a weak and curious up and down motion with the long hindwings streaming in the air much in the manner of ephemerids. It normally haunts houses and flies at dusk. The larvae are found among dust and refuse on floors, feeding on small insects like psocids. The life history is completed in a year (Imms, 1911).

Incidentally, a perusal of the literature revealed no record of nemopterids from Maharashtra State. This is, thus the first record of nemopterids in the state in general and Croce filipennis
Westwood in particular.

The collected specimens measured 6 to $8 \mathrm{~mm}$ in length. The thread-like hind wings are three to five times as long as the body. Globally, the family Nemopteridae is represented by 12 genera and about 50 species (Essig, 1982); only four genera and six species are reported from India (Ghosh, 1998).

\section{Acknowledgement}

We are thankful to Dr. J.R.B. Alfred, Director, Zoological Survey of India, Calcutta and Dr. M.S. Pradhan, Scientist SE and Officerin-Charge Z.S.I. W.R.S. Pune, for facilities and encouragement. Thanks are also due to Dr. D.B. Bastawade, Assistant Zoologist, Z.S.I. W.R.S. Pune for his kind co-operation during survey period.

\section{References}

Essig, E.O. (1982). College Entomology (Indian Print). Satish Book Enterprise, Agra.

Ghosh, S.K. (1998). Neuroptera. In: Alfred, J.R.B. et al. Faunal Diversity of India, pp. 252-257. ENVIS Centre, Zoological Survey of India, Calcutta.

Imms, A.D. (1911). On the life history of Croce filipennis Westwood. Transcripts of the Linnaean Society of London 2(1): 151-160.

Figure 1. Croce filipennis Westwood

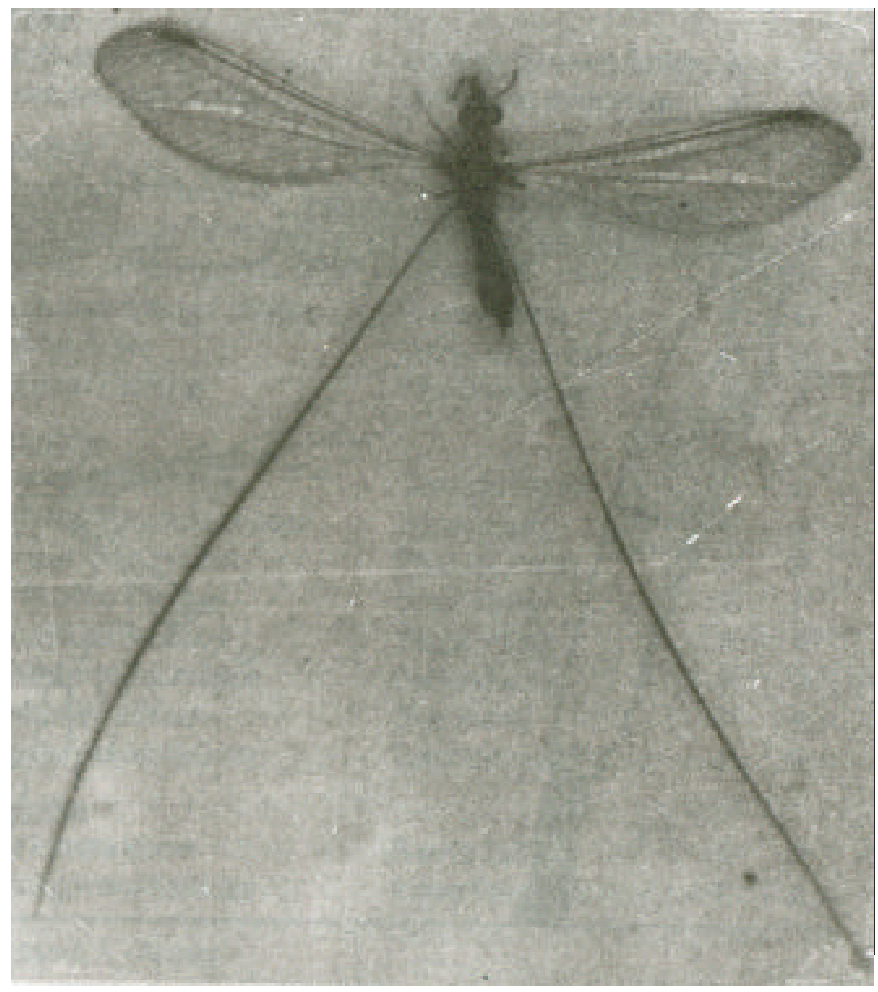

